Insight, part of a Special Feature on Integration of Social and Natural Dimensions of Sustainability

\title{
Preparing the next generation of sustainability scientists
}

$\underline{\text { Alexander K. Killion }}^{1,2}, \underline{\text { Kellev Sterle }}^{3}$, Emily N. Bondank $^{4}, \underline{\text { Jillian R. Drabik }}^{5}, \underline{\text { Abhinandan Bera }}^{6}, \underline{\text { Sara Alian }}^{7}, \underline{\text { Kristen A. Goodrich }}^{8}$, Marcia Hale ${ }^{9,10}$, Rachel A. Myer ${ }^{11}$, Quang Phung ${ }^{12}$, Aaron M. Shew ${ }^{13}$ and Anastasia W. Thayer ${ }^{14}$

\begin{abstract}
Graduate programs emerging in universities over recent decades support the advanced study of sustainability issues in complex socio-environmental systems. Constructing the problem-scope to address these issues requires graduate students to integrate across disciplines and synthesize the social and natural dimensions of sustainability. Graduate programs that are designed to foster inter- and transdisciplinary research acknowledge the importance of training students to use integrative research approaches. However, this training is not available in all graduate programs that support integrative research, often requiring students to seek external training opportunities. We present perspectives from a group of doctoral students with diverse disciplinary backgrounds conducting integrative research in universities across the United States who participated in a 10-day, National Science Foundation-funded integrative research training workshop to learn and develop socio-environmental research skills. Following the workshop, students conducted a collaborative autoethnographic study to share pre- and postworkshop research experiences and discuss ways to increase integrative research training opportunities. Results reveal that students, regardless of disciplinary background, face common barriers conducting integrative research that include: (1) lack of exposure to epistemological frameworks and team-science skills, (2) challenges to effectively include stakeholder perspectives in his/her research, and (3) variable levels of committee support to conduct integrative research. To overcome the identified barriers and advance integrative research, students recommend how training opportunities can be embedded within existing graduate programs. Students advocate that both internal and external training opportunities are necessary to support the next generation of sustainability scientists.
\end{abstract}

Key Words: graduate education; integrative research; interdisciplinary; team science; training; transdisciplinary

\section{INTRODUCTION}

Human development and behavior continue to stress natural resources around the world (Steffen et al. 2011, 2015, Kidwell 2015) and drive global environmental change (Barnett et al. 2008). These human-induced changes to Earth and climate cycles characterize the Anthropocene in which sustainability challenges have grown increasingly complex and intractable (Chakrabarty 2009). In the mid-20th century, M. King Hubbert, Rachel Carson, and E. F. Schumacher, among others, articulated with alarming precision the extent of human-caused harm to environmental systems, seeding the impetus of sustainability research and scholarship. Asserting that "humanity must learn to live within the limitations of the biophysical environment" (Goodland 1995:3), the field of sustainability science recognizes that environmental well-being is critical to human well-being.

Sustainability issues at the nexus of food, water, energy, and ecosystem biodiversity are compounding. Nexus complexities are often driven by unique local conditions, unclear boundaries, ambiguous definitions, and interdependent issues within socioenvironmental systems in which any given solution might generate new problems (Rittel and Webber 1973, Head and Alford 2015). For example, in the 1970s, several nations sought energy independence through subsidizing renewable fuel. However, this shift caused an unexpected rise in food prices across developing countries, forcing 155 million people into poverty (Naylor et al.
2007, Runge and Senauer 2007, de Hoyos and Medvedev 2009). Such compounding complexities are only expected to grow more common and convoluted in the future (Foley et al. 2005, Allenby 2008, Tilman et al. 2011).

No single discipline possesses the knowledge to solve complex sustainability issues, thus an integrative research approach that draws upon diverse academic disciplines and local stakeholder knowledge is needed (Clark and Dickson 2003). We define integrative research inclusive of both interdisciplinary research, in which multiple disciplines jointly focus on a common problem, as well as transdisciplinary research, defined as interdisciplinary research that includes active participation from professionals and stakeholders outside academia (i.e., a person or organization who affect or are affected by a decision or action; Grimble and Wellard 1997, Reed et al. 2009, Brandt et al. 2013) to synthesize and extend discipline-specific approaches (Stokols 2017). Integrative research strives for synergistic versus additive outcomes (Pennington et al. 2016) and is well-equipped to address the problem-driven and solution-oriented nature of sustainability research (Gibbons and Nowotny 2001, Lang et al. 2012, Brandt et al. 2013, Mauser et al. 2013, Stokols 2017).

In practice, integrative research relies heavily on the principles of team-science. In team-science, methodologic strategies are aimed to understand and enhance the outcomes of large-scale collaborative research and training programs (Stokols 2013).

\footnotetext{
${ }^{1}$ Human-Environment Systems Center, Boise State University, ${ }^{2}$ Ecology, Evolution, and Behavior, Boise State University, ${ }^{3}$ Graduate Program of Hydrologic Sciences and Cooperative Extension, University of Nevada, Reno, ${ }^{4}$ School of Sustainable Engineering and the Built Environment, Arizona State University, ${ }^{5}$ Abess Center for Ecosystem Science and Policy, University of Miami, Florida, ${ }^{6}$ Department of Architecture, Pennsylvania State University, ${ }^{7}$ Department of Biosystems and Agricultural Engineering, Oklahoma State University, ${ }^{8}$ School of Social Ecology, University of California, Irvine, ${ }^{9}$ Department of Peace and Conflict Studies, University of North Carolina Greensboro, ${ }^{10}$ California Center for Sustainable Communities, UCLA Institute of the Environment and Sustainability, ${ }^{11}$ Department of Psychology, Temple University, ${ }^{12}$ Bioengineering Department, University of Missouri, ${ }^{13}$ Environmental Dynamics Program, University of Arkansas, ${ }^{14}$ Department of Agricultural Economics, Texas A\&M University
} 
These skills enable disciplinary researchers to effectively communicate in an interdisciplinary research team, cocreate a shared vision of the research problem, and encourage intellectual disagreement that fosters innovative problem-solving (Pennington et al. 2013, Stokols 2013). Research teams can also use teamscience skills to systematically and iteratively incorporate normative knowledge from relevant stakeholder groups, thereby enhancing sustainability research. Using team-science skills, researchers can facilitate more holistic sustainability research by integrating knowledge of social systems (e.g., norms, perceptions, power, and political systems) and environmental systems (e.g., ecological, hydrological, and climatological systems; Komiyama and Takeuchi 2006, Jerneck et al. 2011). Ultimately, this helps academic teams disentangle system complexities and deliver research products useful across diverse disciplines and stakeholders (Van der Leeuw et al. 2012).

Despite a growing number of graduate programs that support inter- and transdisciplinary research opportunities (Stokols 2013, 2017, Borrego et al. 2014, Bosque-Pérez et al. 2016, Haider et al. 2018), training students to conduct integrative research confronts major challenges (Crow 2010, Vincent et al. 2015, Pennington et al. 2016, Lindvig 2018, Trencher et al. 2018). The traditional silo structure (i.e., single discipline) of academic institutions can limit students' exposure to different disciplines (Bozeman and Boardman 2003, Amey and Brown 2004, Sá 2008, Crow and Dabars 2013, Borrego et al. 2014). Formulating integrative research questions requires students to hold disciplinary depth to address specific complexity in their field. This also requires students to hold enough interdisciplinary breadth to understand how other disciplines view the problem and approach problem-solving, and to be able to communicate perspectives across disciplines (Eigenbrode et al. 2007, Morse et al. 2007, Holley 2015, National Research Council 2015, BosquePérez et al. 2016). However, transforming the traditional silo structure to accommodate multidisciplinary coursework needed to achieve interdisciplinary breadth can be difficult or impractical given the goals of a university department (Lang et al. 2012, Yarime et al. 2012).

Practicing team-science skills in an applied research setting is also as important as students' interdisciplinary breadth (Ashley and Carney 1999, Looney et al. 2013, Romolini et al. 2013, Stokols 2013). For example, students who participate in a research team gain experience implementing integrative research frameworks (e.g., social-ecological systems framework, sustainable livelihood approach, vulnerability framework) and learn firsthand the disciplinary differences in interpretation of those frameworks (Cutter 1996, Krantz 2001, Ostrom 2009). Without both multidisciplinary coursework and applied research experience, students may have difficulty developing an interdisciplinary dissertation research topic (Holley 2015), learning team-science skills to facilitate research goals and objectives (Looney et al. 2013), and communicating his/her research to diverse and nonacademic audiences (Bosque-Pérez et al. 2016). As opposed to waiting for institutional reform (Karlin et al. 2016), students may instead seek external research training opportunities to facilitate a more holistic graduate research experience (Boden et al. 2011).
We present perspectives from a group of disciplinarily diverse doctoral students conducting integrative research (i.e., the authors) who sought an external research training workshop to learn and develop socio-environmental research skills to improve his/her doctoral research. Following the workshop, students conducted a collaborative autoethnographic study (Meyer et al. 2016) to share pre- and postworkshop research experiences and discuss ways to increase the availability of integrative research training opportunities.

\section{METHODS}

During the summers of 2016 and 2017, two cohorts of 13 doctoral students enrolled in 21 different universities across the United States participated in the 10-day, National Science Foundationfunded Employing Model-Based Reasoning in SocioEnvironmental Synthesis (EMBeRS) workshop held at the University of Texas at El Paso (Pennington et al. 2016). The doctoral students had backgrounds in the social, physical, natural, engineering, and health sciences, and were conducting integrative sustainability research as part of their doctoral studies. The EMBeRS workshop introduced students to model-based reasoning to investigate wicked problems, acknowledging that researchers reason through complex sustainability issues by constructing an internal mental model of the situations, events, and processes that they encounter (Table 1). The workshop used boundary negotiating objects to teach team-science skills, which are external representations useful to facilitate communication of different mental models and link different perspectives. For example, boundary negotiating objects can be developed through conceptual mapping activities in which students externalize mental models on paper or through system-dynamics model building software.

The workshop utilized a case-study approach in which students worked in small groups of four-five students to apply model-based reasoning and develop team-science skills surrounding a realworld water resource issue. Case-study topics included challenges to water sustainability under a changing climate in Mexico City (cohort 2016) and the Rio Grande River basin (cohort 2017). To introduce stakeholder perspectives, the workshop featured field trips to diverse local stakeholder communities, including representatives of water utility districts, regulatory water managers, agricultural irrigators, and environmental stewards. Ultimately, the goal was for students to gain pragmatic integrative research experience and learn how to implement the EMBeRS model within their own research (Thompson et al. 2017).

Following the 2017 workshop, students engaged in several informal discussions to reflect on their integrative research experiences. The discussion converged on five topics: (1) previous integrative research training, (2) experience within current graduate programs, (3) barriers encountered in conducting integrative research, (4) aspects of the EMBeRS approach most useful to overcome identified barriers, and (5) recommendations for the future of integrative research training. A set of open-ended survey questions were administered to both cohorts through a web-based form (i.e., Google Forms; Appendix 1) to formalize insights from these discussions, and compare and contrast experiences across students. Twelve of the 26 students voluntarily participated and transcribed their perspectives. Although the 
Table 1. Employing Model-Based Reasoning in Socio-Environmental Synthesis (EMBeRS) workshop topics and activities, modified from 2017 agenda.

\begin{tabular}{ll}
\hline \hline Topic & Activity/Purpose \\
\hline $\begin{array}{l}\text { Challenges of interdisciplinary research and the EMBeRS } \\
\text { Approach }\end{array}$ & $\begin{array}{l}\text { Share your research with others verbally without using jargon } \\
\text { and visually using a conceptual model }\end{array}$ \\
$\begin{array}{l}\text { Dispositional characteristics, disciplinary cultures, and team } \\
\text { Ecience }\end{array}$ & $\begin{array}{l}\text { Establish small groups, share disciplinary backgrounds, and } \\
\text { learn about each other's role in a team setting } \\
\text { Stakeholder analysis }\end{array}$ \\
$\begin{array}{l}\text { Participate in half-day field trips to urban, environmental, } \\
\text { agricultural, and regulatory water-use communities in the Rio }\end{array}$ \\
$\begin{array}{l}\text { Grande River basin } \\
\text { Identify the problem and solution as viewed through your } \\
\text { disciplinary lens, as well as through the lens of river basin } \\
\text { stakeholders }\end{array}$ \\
$\begin{array}{l}\text { Negotiate a framework within a disciplinarily diverse team } \\
\text { Model formulation using computer programs } \\
\text { Construct research questions and an integrated conceptual } \\
\text { Using socio-environmental frameworks }\end{array}$ & $\begin{array}{l}\text { model for a research proposal } \\
\text { Practice facilitating research-team activities on other small } \\
\text { groups }\end{array}$ \\
Mock solicitation & Reflective writing \\
\hline Designing interdisciplinary research programs and activities &
\end{tabular}

voluntary sample methodology produced results representative only of students who chose to participate, nevertheless, our sample reflected perspectives of doctoral students enrolled in disciplinary diverse programs from 12 different universities across the United States.

Using a collaborative autoethnographic approach (e.g., Meyer et al. 2016), five students independently coded the anonymous responses to identify emergent themes (Creswell and Creswell 2017). As part of an intercoder reliability assessment (Lombard et al. 2002), the five students collaboratively shared coding to finalize three themes. These themes were further validated by the remaining seven students to ensure themes reflected shared perspectives. The resulting themes were: (1) students share common barriers to conducting integrative research regardless of disciplinary background; (2) students describe the utility of integrative research training to overcome identified barriers; and (3) students endorse embedding training opportunities into existing programs. The following sections summarize each theme, citing the most frequently mentioned responses, and present quotes to illustrate individual perspectives.

\section{RESULTS}

\section{Common barriers to conducting integrative research}

All of the students, regardless of discipline, described barriers in conducting integrative research. The three most cited barriers were: (1) lack of exposure to epistemological frameworks and team-science skills, (2) challenges to effectively include stakeholder perspectives in his/her research, and (3) variable levels of committee support to conduct integrative research.

Lack of exposure to epistemological frameworks and teamscience skills

A lack of exposure to different epistemological and integrative research frameworks was described as a barrier to integrate information across the problem scope. Students described how researchers from different disciplines have different ways of creating, acquiring, and communicating knowledge, and thus have different epistemological frameworks (e.g., Guba and Lincoln 1994, Cohen et al. 2002, Scotland 2012). For example, some disciplines are founded on objectivism in which knowledge about cause and effect can be discovered from objective reality through experimentation and empirical trials (Crotty 1998, Scotland 2012, Creswell and Creswell 2017). Another epistemological framework is subjectivism in which meaning is not discovered but rather constructed through the interaction between consciousness and the world, and truth is a consensus formed by coconstructors (Pring 2000, Grix 2010, Scotland 2012). Students described that integrative research was made more difficult when course requirements were "pre-determined and supportive of only core [writing and mathematics] courses outside the discipline" and they are not exposed to different epistemological frameworks.

Students shared that without formal training in team-science skills or project management, communication and collaboration in disciplinarily diverse teams is difficult. One engineering student shared an example from an interdisciplinary team comprised of several social scientists. The team was tasked with creating an integrated decision-making tool to assess climate change adaptation. In this team setting, researchers did not systematically and diplomatically communicate their perspectives as to the types of knowledge they believed were useful for the decision-making tool. As a result, they did not collaboratively integrate their perspectives, and the research objectives became heterogeneous among members. Only isolated, and often conflicting, multidisciplinary products such as actor maps, institutional narratives, and physical systems dynamics models were produced.

Other students shared examples from projects in which team conflict had ultimately ended collaborations. As reflected by one 
student: "looking back, simple team-building or mediation tools could have saved the project." Most students described how their doctoral programs offered "no formal training to understand or navigate team dispositions and address conflict within teams," which could be practiced in example situations described above. For most, the EMBeRS workshop was the first opportunity to practice team-science skills. Prior to the workshop, few felt wellequipped to lead exercises promoting effective communication practices among team members.

\section{Challenges to effectively include stakeholder perspectives in his/ her research}

Students reported four common challenges to effectively include stakeholders and their perspectives in his/her doctoral research. These challenges included: (1) difficulty engaging with relevant and willing stakeholder groups, (2) incorporating conflicting stakeholder opinions into a shared vision, (3) prioritizing stakeholder engagements among other program coursework, and (4) using stakeholder perspectives to understand the problem scope in its entirety.

Prior to the EMBeRS workshop, few students were aware of participatory research frameworks that incorporate stakeholders and harness diverse perspectives early and throughout the research process. For example, several students noted their project failed to include stakeholders in the initial problem scoping stage. When they did attempt to include them, conflicting perspectives dissuaded further participation. As another example, a student involved with a regional water study described challenges eliciting knowledge from a sensitive stakeholder group that had faced media criticism for harmful environmental action. This student had to decide whether or not to spend a significant amount of time building trust and incorporating their perspectives while maintaining other program duties.

Following the EMBeRS workshops, students described that visiting, listening, and communicating with diverse stakeholder communities before defining the problem scope was integral for developing shared, relevant research questions within their groups. For example, without the field trips to diverse water use communities in the Rio Grande River basin, students recognized that their perspectives of water-related issues would have been biased to the systems they are most familiar with. As one student described: "Seeing that the utility district uses an extensive desalinization process to make groundwater usable made me realize the key issue in this river basin may be energy [to pump, treat, and deliver water] versus water quantity."

\section{Variable levels of committee support to conduct integrative} research

Students reported faculty mentorship and advising early in the doctoral program as critical to shape integrative research design, increasing students' ability to adhere to doctoral program and research timelines. However, students described that misalignments between student and committee members' research goals, and whether they are truly inter- or transdisciplinary, can jeopardize students' integrative research experience. Additionally, students described the rarity of multidisciplinary committee members providing cohesive commitment to a specific research direction.

As a result, students reported spending more time to build and defend their research than students pursuing more traditional disciplinary research. As one student reflected: "I spend a significant amount of time communicating with [disciplinarily diverse] committee members just to ensure everyone is on the same page." Even when everyone agrees on the research direction and committee members are supportive of integrative research, students described how publishing in interdisciplinary journals is generally discouraged, and instead were advised to compartmentalize results to be published in multiple disciplinedriven journals.

Students described that pursuing integrative research without willing collaborators resulted in larger individual workloads, making it difficult to maintain doctoral program and research timelines. As one student reflected: "Developing a working knowledge of multiple disciplines necessary to apply a mixedmethods approach takes significantly more time and effort."Some students described how this reality left them questioning whether they would pursue future integrative research opportunities after earning their doctoral degree. Students also acknowledged challenges finding integrative training opportunities under limited funding and/or misalignment with department goals.

\section{Utility of integrative research training}

Prior to the EMBeRS workshop, most students had obtained informal integrative research training through hands-on participation in interdisciplinary research projects, trial-anderror in his/her own research, or interactions with faculty or peers from other disciplines. Although some students described formal training opportunities at his/her university, most students had taken the initiative to seek external opportunities, such as the EMBeRS workshop.

Students described that the approaches to foster collaboration within academic teams and stakeholders taught during the EMBeRS workshop were the most useful to address identified barriers, i.e., lack of exposure to epistemological frameworks and team-science skills, challenges to effectively include stakeholder perspectives in the research, and variable levels of committee support to conduct integrative research. For example, building boundary negotiating objects and conceptual visualizations individually, and then cocreating as a team, was described as highly effective to negotiate perspectives, practice team-science skills, and eliminate frustration and confusion commonly encountered in research teams. Students described the field trips to diverse stakeholder communities (e.g., Rio Grande River basins municipal and industrial, regulatory, agricultural, and environmental communities) as additional boundary negotiating objects instrumental to incorporate stakeholders' perspectives of the problem scope. Incorporating these perspectives facilitated further practice communicating epistemological frameworks and developing integrative research questions that capture a more holistic vision of the problem.

Students described that team-science skills introduced at the beginning of the workshop and practiced throughout (e.g., active listening, identifying motivations and values, and creating communication rules) were instrumental to develop the final mock research proposal. As one student described: "Having the time to practice collaboration in a low-risk environment affirmed that a prescriptive path for a successful collaboration is nonexistent and must be adaptable." As another student reflected: "Interdisciplinary research is hard and coming to an agreement 
on questions or methods takes time and iterative respectful conversations."

Following the EMBeRS workshop, students shared new approaches to overcome identified barriers, higher confidence to complete his/her doctoral research, and aspirations to develop and lead future integrative research trainings. As one student described: "The workshop gave me the confidence I needed to complete my research. Using the EMBeRS approaches, I can better focus and not be so frustrated with the process it may take." Students described returning from the workshop with a greater recognition of the importance of diverse perspectives. As another student shared: "The workshop provided a space for exposure and connection with other student researchers experientially instilling a recognition that diverse groups are fun and productive when managed effectively."

Several students shared how they are incorporating EMBeRS approaches to overcome barriers in doctoral research. Projects include identifying infrastructure adaptation strategies to climate change in the United States desert southwest, examining locally identified adaptation strategies to respond to changing snowpack in the Truckee-Carson River system of northwestern Nevada (Singletary and Sterle 2017, Sterle and Singletary 2017), modeling surface and groundwater systems to assess changing water supply in the Rio Grande River basin, defining economic policy and sustainable development initiatives in southern Africa (Shew et al. 2018), and supporting climate change adaptation in a binational community on the U.S.-Mexico border (Goodrich et al. 2018). Additionally, students described how they are utilizing integrative research trainings in teaching (e.g., life cycle assessment and industrial ecology) and are building integrative research communities that meet monthly to discuss the future of sustainability research at their universities.

\section{Embedding integrative research training in existing graduate programs}

Students shared recommendations for how integrative research training might enhance graduate programs and research experiences for future students. Overwhelmingly, students asserted that doctoral programs need to provide opportunities to learn: (1) the basics of multiple epistemological and integrative frameworks; and (2) collaboration and team-science skills in an experiential setting.

Students favored embedding integrative research training into existing graduate programs and coursework to initiate exposure to and facilitate an understanding of epistemological frameworks and discipline-specific research methods. Figure 1 presents specific integrative research training opportunities identified by students that can be implemented into existing graduate programs. Opportunities are ranked accordingly to disciplinary program alignment (i.e., the likelihood an activity could coexist with the single-discipline goals of the graduate program) and effort required to implement.

To fill the experiential learning gap, students recommended developing short (two-days to two-weeks) training workshops that bring students together to work on relevant natural resource issues in a case study area of interest. Students recommended that workshop activities prioritize teaching team-science skills and methods to navigate dispositional differences, and provide applied research opportunities to practice conceptual mapping and cocreate a shared vision of the research problem. Exposure could also be initiated by including an interdisciplinary lecture within an existing weekly department seminar series and announcing to other departments across campus. At the University of California Irvine, first-year students are required to attend seminars that introduce different epistemological frameworks. This encourages the development of novel mental models and catalyzes an increased use of interdisciplinary concepts and methods in doctoral research (Mitrany and Stokols 2005).

Fig. 1. Integrative research training opportunities that can be implemented into existing graduate programs. Opportunities are ranked according to disciplinary program alignment (i.e., the likelihood an activity could coexist with the single-discipline goals of a graduate program; low to high, y-axis) and effort required to implement (low to high, $x$-axis). Shading indicates the potential impact of training opportunities to instill integrative research skills needed by future sustainability scientists (high, medium, low).

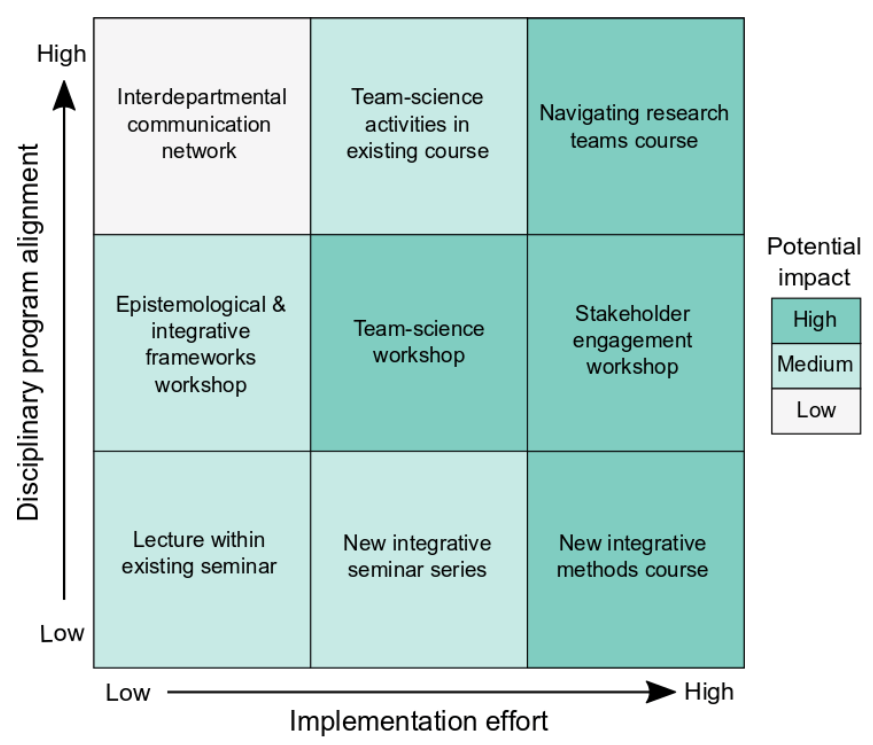

\section{DISCUSSION}

As a group of disciplinarily diverse doctoral students, we collectively recognize the importance and necessity of collaborative, experiential learning in sustainability research that incorporates multiple disciplines and engages local stakeholders (Meyer et al. 2016, Trencher et al. 2018). As we have recommended, pairing exposure to applied case study research with training opportunities to practice team-science skills has been shown to improve integrative research outcomes (Rhoten and Parker 2004, Bammer 2005, Kessel et al. 2008, Callahan 2010, Stokols 2013). Creating additional training opportunities and a community of integrative researchers to share successes and failures can help students overcome common team-science issues (Graybill et al. 2006, Newswander and Borrego 2009, Boden et al. 2011), while also exposing students to stakeholder perspectives and the importance of the normative nature of sustainability research (Jerneck et al. 2011). 


\section{Recommendations for students}

During the EMBeRS training, the Toolbox Dialogue Initiative was introduced as a learning exercise to uncover differences in team member's epistemological positions. This approach provides guided activities that identify underlying disciplinary assumptions of the nature, conduct, and application of students' research and can help navigate roadblocks that arise within different epistemological frameworks (Eigenbrode et al. 2007, Schnapp et al. 2012, Looney et al. 2013, O'Rourke and Crowley 2013). Using boundary negotiating objects to conceptually map a research problem can also help students negotiate differences and identify integrative research opportunities (Heemskerk et al. 2003, Hay and Kinchin 2006, Pennington et al. 2016). Students wishing to broaden their familiarity with different epistemological frameworks and how different epistemologies elicit different types of research questions may find Moon and Blackman (2014) a useful initial resource in which the authors present a guide to navigate the philosophical basis of social science using various characteristics of ontologies, epistemologies, and theoretical perspectives. In addition to reading foundational papers from different disciplines, we recommend students make it a priority to connect with students from different disciplines and learn about their research and reasoning behind their methodological approaches. Self-motivated, cross-disciplinary discussions can also foster team-science skills. Prior to engaging in collaborative research efforts, we also suggest that students first work to identify their own motivations and values regarding their involvement in sustainability research (Bennett et al. 2010).

To improve the integration of stakeholders in the research process, the use of communication tools can help guide structured dialogue during stakeholder engagements to harness diverse perspectives, assumptions, and norms (Van der Leeuw et al. 2012). Moreover, the use of integrative frameworks and conceptual mapping are useful for incorporating stakeholder knowledge and perspectives in the research design. This application may help students better identify linkages between social and natural dimensions of sustainability and improve their ability to make holistic sustainability recommendations (Komiyama and Takeuchi 2006, Averyt 2010). We recommend that students preparing to conduct research with stakeholders first become knowledgeable of methods to identify stakeholders (Reed et al. 2009, Lelea et al. 2014, Leventon et al. 2016) and best practices of stakeholder participation and engagement (Creighton 2005, Reed 2008, Reed et al. 2014). We also note the importance of developing a stakeholder communication and engagement plan early on in the research process to anticipate and plan around other graduate program requirements while simultaneously meeting stakeholder needs.

Because the path of integrative research in traditional singlediscipline programs is often unpaved, students easily become overwhelmed with the task of learning multiple disciplines, designing feasible projects, and working on an interdisciplinary research team (Hibbert et al. 2014). A similar study found that students who take more time to develop a shared vision across their graduate committee at the program outset, prioritize communication skills, and brought an entrepreneurial attitude had higher success answering their research questions (Record et al. 2016). Creating an integrative research community of current doctoral students and recent graduates, mentored by supportive faculty, can serve as an important first step in preparing students to navigate sustainability issues in socio-environmental systems research (Ryan et al. 2012, Hibbert et al. 2014, Holley 2015).

\section{Advancements in integrative research training}

As interest in integrative research continues to grow (Van Noorden 2015), new academic and professional arenas for integrative research have emerged (Gornish et al. 2013, Gewin 2014, Goring et al. 2014). For example, the National SocioEnvironmental Synthesis Center (SESYNC) provides opportunities for doctoral students to conduct interdisciplinary research with students from other universities independent of their dissertation work (Palmer et al. 2016). The SESYNC provides facilitation training and experience coleading and/or participating in a research team of peers, and managing project deliverables. Rather than providing services as an external center, the Integrative Graduate Education and Research Traineeship (IGERT) generated integrative research training and catalyzed cultural change at institutions across the United States to support collaborative cross-disciplinary research and sought to maintain a broad perspective and improve team-science skills (Borrego and Cutler 2010). These programs promoted institutional policy changes conducive to interdisciplinary collaboration, created new integrative graduate courses, and increased overall student participation in cross-disciplinary team science (Carney et al. 2006, Borrego and Cutler 2010, Borrego et al. 2014, Keck et al. 2017).

Innovative means to embed integrative research skills within graduate programs have been developed around the world. The Stockholm Resilience Centre has emphasized building collaborative networks, designing workshops, running participatory processes, and integrating across social and natural dimensions as core skills expected from $\mathrm{PhD}$ students. Lund University has also been a leader in interdisciplinary and sustainability research and education. At Lund, the PhD program was formed by integrating six diverse existing disciplines across the university to better support students researching complex sustainability issues. Similarly, students of human-environment systems at Boise State University take courses to learn the foundations of transdisciplinary research and how to integrate quantitative and qualitative methodologies. Arizona State University has developed multiple transdisciplinary schools and requires $\mathrm{PhD}$ students to enroll in "solution workshops" in which student-led projects address real community-based problems where their plans are often implemented with local decision makers or stakeholders. Likewise, the Helmholtz Interdisciplinary Graduate School for the Environmental Research developed a program for their PhD students to practice team-science skills by forming a team of interdisciplinary and international students to conduct an independent synthesis project. These examples can serve as templates of best practices and inform new efforts to improve the training of sustainability scientists in other institutions.

\section{The role of institutional structure}

We acknowledge that the feasibility of incorporating integrated research training into existing graduate programs relies on department support for integrative research, faculty collaboration (Evans 2015), and ongoing student participation to provide feedback on coursework, and to organize and advertise workshops and research networks. However, entrepreneurial 
efforts to embed integrative education in traditional programs have proven to be successful (Lindvig et al. 2017). Training opportunities identified by students in this study, such as developing a new team-science course or hosting stakeholder and team-science workshops are feasible and could generate high impact training (Fig. 1). The higher level of effort required to implement a new course on navigating research teams, for example, could be offset by high program alignment because these are skills that also benefit students working within a single discipline. Conversely, adding activities or lectures to existing coursework require lower levels of implementation effort because the courses are already scheduled, but may be less impactful (Fig. 1). Specific attention should be given to the implementation of course or workshop activities to ensure all students involved have a strong interest in the outcome and direction of the work (to resemble a true team-science experience), and have different disciplinary backgrounds. The ability to cross-list courses (i.e., more than one department offering the course) can significantly impact the availability of diverse student expertise for sustainability projects and the quality of integration.

Sustainability and integrative research training can be provided in many ways within an academic institution. These forms have included independent interdisciplinary departments, collaborative research centers within a college, institutes that report to the university, or different formal and informal cross-departmental collaborations (Vincent et al. 2015). Feasibility to incorporate specific training opportunities will likely vary depending on institutional structure. However, even without formal institutional structures that support integrative research, opportunities still exist within and among single discipline departments to better prepare sustainability scientists to address complex issues (Lyall et al. 2015, Lindvig 2017). Ultimately, students and faculty should work together to develop and instill sustainable activities that promote integrative research skills within their specific graduate program.

\section{CONCLUSION}

Investigating sustainability issues in socio-environmental systems requires integrative research approaches sensitive to complexity. Although integrative (i.e., interdisciplinary and transdisciplinary) research approaches provide such instruments, there are currently many institutional barriers associated with integrative research on the ground, especially at the graduate level. A collaborative autoethnographic study conducted by doctoral students identified common barriers to conducting integrative research, including lack of exposure to diverse epistemological frameworks and team-science skills, barriers to including stakeholder perspectives in his/her research, and variable levels of faculty support to conduct integrative research.

To address these barriers, students recommend that integrative research training opportunities be made more available within existing graduate programs to give students the opportunity to practice working across disciplines and engaging with stakeholders communities. These opportunities could be incorporated into existing coursework, seminars, experiential learning workshops, and new research communities of practice. These recommendations can serve to support future sustainability scientists investigating complex socio-environmental systems, thereby advancing the integration of social and natural dimensions in sustainability research.
Responses to this article can be read online at: http://www.ecologyandsociety.org/issues/responses. php/10395

\section{Acknowledgments:}

We thank the Special Feature editors and three anonymous reviewers for their thoughtful comments and recommendations. We also thank Deana Pennington and the other EMBeRS workshop facilitators for their kindness and dedication to improving graduate education. This research was supported by the Ecology, Evolution, and Behavior Program at Boise State University and the following U.S. National Science Foundation (NSF) Awards: The NSF Idaho EPSCoR Program [Grant No. IIA-1301792]; The NSF South Florida Water, Sustainability, and Climate Project [Grant No. EAR-1204762]; The NSF Urban Water Innovation Network Project [Grant No. CBET-1444758]; The NSF Division of Earth Sciences Water Sustainability and Climate Program [Grant No. 1360506]; The NSF Division of Graduate Education [Grant No. 1545404]; and The NSF Graduate Research Fellowship Program [Grant No. DGE-1450079].

\section{LITERATURE CITED}

Allenby, B. 2008. The Anthropocene as media: information systems and the creation of the human earth. American Behavioral Scientist 52(1):107-140. http://dx.doi.org/10.1177/0002764208321345

Amey, M. J., and D. F. Brown. 2004. Breaking out of the box: interdisciplinary collaboration and faculty work. Information Age, Charlotte, North Carolina, USA.

Ashley, C., and D. Carney. 1999. Sustainable livelihoods: lessons from early experience. Department for International Development, London, UK.

Averyt, K. 2010. Are we successfully adapting science to climate change? Bulletin of the American Meteorological Society 91 (6):723-726. http://dx.doi.org/10.1175/2010BAMS2906.1

Bammer, G. 2005. Integration and implementation sciences: building a new specialization. Ecology and Society 10(2):6. http:// dx.doi.org/10.5751/ES-01360-100206

Barnett, J., R. A. Matthew, and K. O'Brien. 2008. Global environmental change and human security. Pages 355-361 in $\mathrm{H}$. G. Brauch, Ú O. Spring, C. Mesjasz, J. Grin, P. Dunay, N. C. Behera, B. Chourou, P. Kameri-Mbote, and P. H. Liotta, editors. Globalization and environmental challenges. Springer, Berlin, Germany. http://dx.doi.org/10.1007/978-3-540-75977-5 24

Bennett, L. M., H. Gadlin, and S. Levine-Finley. 2010. Collaboration and team science: a field guide. National Institutes of Health, Bethesda, Maryland, USA.

Boden, D., M. Borrego, and L. K. Newswander. 2011. Student socialization in interdisciplinary doctoral education. Higher Education 62(6):741-755. http://dx.doi.org/10.1007/s10734-011-9415-1

Borrego, M., D. Boden, D. Pietrocola, C. F. Stoel, R. D. Boone, and M. K. Ramasubramanian. 2014. Institutionalizing interdisciplinary graduate education. Pages 335-355 in $\mathrm{M}$. O'Rourke, S. Crowley, S. D. Eigenbrode, and J. D. Wulfhorst, editors. Enhancing communication and collaboration in 
interdisciplinary research. Sage, Thousand Oaks, California, USA. http://dx.doi.org/10.4135/9781483352947.n16

Borrego, M., and S. Cutler. 2010. Constructive alignment of interdisciplinary graduate curriculum in engineering and science: an analysis of successful IGERT proposals. Journal of Engineering Education 99(4):355-369. http://dx.doi.org/10.1002/ j.2168-9830.2010.tb01068.x

Bosque-Pérez, N. A., P. Z. Klos, J. E. Force, L. P. Waits, K. Cleary, P. Rhoades, S. M. Galbraith, A. L. B. Brymer, M. O'Rourke, S. D. Eigenbrode, B. Finegan, J. D. Wulfhorst, N. Sibelet, and J. D. Holbrook. 2016. A pedagogical model for team-based, problemfocused interdisciplinary doctoral education. BioScience 66 (6):477-488. http://dx.doi.org/10.1093/biosci/biw042

Bozeman, B., and C. Boardman. 2003. Managing the new multipurpose, multidiscipline university research centers: institutional innovation in the academic community IBM Center for the Business of Government, Washington, D.C., USA. [online] URL: http://www.businessofgovernment.org/sites/default/ files/UniversityResearchCenter.pdf

Brandt, P., A. Ernst, F. Gralla, C. Luederitz, D. J. Lang, J. Newig, F. Reinert, D. J. Abson, and H. von Wehrden. 2013. A review of transdisciplinary research in sustainability science. Ecological Economics 92:1-15. http://dx.doi.org/10.1016/j.ecolecon.2013.04.008

Callahan, D. 2010. A memoir of an interdisciplinary career. Page 419 in R. Frodeman, J. Klein, and C. Mitcham, editors. The Oxford handbook of interdisciplinarity. Oxford University Press, New York, New York, USA.

Carney, J., D. Chawla, A. Wiley, and D. Young. 2006. Evaluation of the initial impacts of the National Science Foundation's integrative graduate education and research traineeship program: final report. Abt Associates, Bethesda, Maryland, USA. [online] URL: https://files.eric.ed.gov/fulltext/ED546148.pdf

Chakrabarty, D. 2009. The climate of history: four theses. Critical Inquiry 35(2):197-222. http://dx.doi.org/10.1086/596640

Clark, W. C., and N. M. Dickson. 2003. Sustainability science: the emerging research program. Proceedings of the National Academy of Sciences 100(14):8059-8061. http://dx.doi.org/10.1073/ pnas. 1231333100

Cohen, L., L. Manion, and K. Morrison. 2002. Research methods in education. Routledge, London, UK.

Creighton, J. L. 2005. The public participation handbook: making better decisions through citizen involvement. John Wiley and Sons, San Francisco, California, USA.

Creswell, J. W., and J. D. Creswell. 2017. Research design: qualitative, quantitative, and mixed methods approaches. Sage, Thousand Oaks, California, USA.

Crotty, M. 1998. The foundations of social research: meaning and perspective in the research process. Sage, Thousand Oaks, California, USA.

Crow, M. M. 2010. Organizing teaching and research to address the grand challenges of sustainable development. Bioscience 60 (7):488-489. http://dx.doi.org/10.1525/bio.2010.60.7.2
Crow, M. M., and W. B. Dabars. 2013. Interdisciplinarity as a design problem: toward mutual intelligibility among academic disciplines in the American research university. Pages 294-322 in M. O'Rourke, S. Crowley, S. D. Eigenbrode, and J. D. Wulfhorst, editors. Enhancing communication and collaboration in interdisciplinary research. Sage, Thousand Oaks, California, USA. http://dx.doi.org/10.4135/9781483352947.n14

Cutter, S. L. 1996. Vulnerability to environmental hazards. Progress in Human Geography 20(4):529-539. http://dx.doi. org/10.1177/030913259602000407

de Hoyos, R. E., and D. Medvedev. 2009. Poverty effects of high food prices: a global perspective. Policy Research Working Paper No. 4887. Development Prospects Group, The World Bank, Washington, D.C., USA.

Eigenbrode, S. D., M. O'Rourke, J. D. Wulfhorst, D. M. Althoff, C. S. Goldberg, K. Merrill, W. Morse, M. Nielsen-Pincus, J. Stephens, L. Winowiecki, and N. A. Bosque-Pérez. 2007. Employing philosophical dialogue in collaborative science. BioScience 57(1):55. http://dx.doi.org/10.1641/B570109

Evans, T. L. 2015. Transdisciplinary collaborations for sustainability education: institutional and intragroup challenges and opportunities. Policy Futures in Education 13(1):70-96. http:// dx.doi.org/10.1177/1478210314566731

Foley, J. A., R. DeFries, G. P. Asner, C. Barford, G. Bonan, S. R. Carpenter, F. S. Chapin, M. T. Coe, G. C. Daily, H. K. Gibbs, J. H. Helkowski, T. Holloway, E. A. Howard, C. J. Kucharik, C. Monfreda, J. A. Patz, I. C. Prentice, N. Ramankutty, and P. K. Snyder. 2005. Global consequences of land use. Science 309 (5734):570-574. http://dx.doi.org/10.1126/science.1111772

Gewin, V. 2014. Interdisciplinary research: break out. Nature 511 (7509):371-373. http://dx.doi.org/10.1038/nj7509-371a

Gibbons, M., and H. Nowotny. 2001. The potential of transdisciplinarity. Pages 67-80 Transdisciplinarity: joint problem solving among science, technology, and society. Springer, New York, New York, USA. http://dx.doi.org/10.1007/978-3-0348-8419-8 7

Goodland, R. 1995. The concept of environmental sustainability. Annual Review of Ecology and Systematics 26(1):1-24. http://dx. doi.org/10.1146/annurev.es.26.110195.000245

Goodrich, K. A., D. Boudreau, J. A. Crooks, A. Eguiarte, and J. Lorda. 2018. The role of community capitals in climate change adaptation in binational setting. InChapter P. R. Lachapelle and D. E. Albrecht, editors. Addressing climate change at the community level in the United States. Community development research and practice series. Routledge, London, U.K.

Goring, S. J., K. C. Weathers, W. K. Dodds, P. A. Soranno, L. C. Sweet, K. S. Cheruvelil, J. S. Kominoski, J. Rüegg, A. M. Thorn, and R. M. Utz. 2014. Improving the culture of interdisciplinary collaboration in ecology by expanding measures of success. Frontiers in Ecology and the Environment 12(1):39-47. http://dx. doi.org/10.1890/120370

Gornish, E. S., J. A. Hamilton, A. Barberán, B. M. Benito, A. Binzer, J. E. DeMeester, R. Gruwez, B. Moreira, S. Taheri, S. Tomiolo, C. Vinagre, P. Vuarin, and J. Weaver. 2013. 
Interdisciplinary climate change collaborations are essential for early-career scientists. Eos, Transactions American Geophysical Union 94(16):151-151. http://dx.doi.org/10.1002/2013EO160003

Graybill, J. K., S. Dooling, V. Shandas, J. Withey, A. Greve, and G. L. Simon. 2006. A rough guide to interdisciplinarity: graduate student perspectives. BioScience 56(9):757-763. http://dx.doi. org/10.1641/0006-3568(2006)56[757:ARGTIG]2.0.CO;2

Grimble, R., and K. Wellard. 1997. Stakeholder methodologies in natural resource management: a review of principles, contexts, experiences and opportunities. Agricultural Systems 55 (2):173-193. http://dx.doi.org/10.1016/S0308-521X(97)00006-1

Grix, J. 2010. The foundations of research. Palgrave Macmillan, Basingstoke, UK.

Guba, E. G., and Y. S. Lincoln. 1994. Competing paradigms in qualitative research. Handbook of Qualitative Research 2 (163-194):105-117. [online] URL: https://eclass.uoa.gr/modules/ document/file.php/PPP356/Guba \%20\%26\%20Lincoln \%201994.pdf

Haider, L. J., J. Hentati-Sundberg, M. Giusti, J. Goodness, M. Hamann, V. A. Masterson, M. Meacham, A. Merrie, D. Ospina, C. Schill, and H. Sinare. 2018. The undisciplinary journey: earlycareer perspectives in sustainability science. Sustainability Science 13(1):191-204. http://dx.doi.org/10.1007/s11625-017-0445-1

Hay, D. B., and I. M. Kinchin. 2006. Using concept maps to reveal conceptual typologies. Education and Training 48(2/3):127-142. http://dx.doi.org/10.1108/00400910610651764

Head, B. W., and J. Alford. 2015. Wicked problems: implications for public policy and management. Administration and Society 47 (6):711-739. http://dx.doi.org/10.1177/0095399713481601

Heemskerk, M., K. Wilson, and M. Pavao-Zuckerman. 2003. Conceptual models as tools for communcation across disciplines. Conservation Ecology 7(3):8. http://dx.doi.org/10.5751/ES-00554-070308

Hibbert, K., L. Lingard, M. Vanstone, E. A. Kinsella, P. McKenzie, A. Pitman, T. D. Wilson, K. Hibbert, L. Lingard, M. Vanstone, E. A. Kinsella, P. Mckenzie, A. Pitman, and T. D. Wilson. 2014. The quest for effective interdisciplinary graduate supervision: a critical narrative analysis. Canadian Journal of Higher Education 44(2):85-104. [online] URL: https://files.eric.ed. gov/fulltext/EJ1038378.pdf

Holley, K. A. 2015. Doctoral education and the development of an interdisciplinary identity. Innovations in Education and Teaching International 52(6):642-652. http://dx.doi.

org/10.1080/14703297.2013.847796

Jerneck, A., L. Olsson, B. Ness, S. Anderberg, M. Baier, E. Clark, T. Hickler, A. Hornborg, A. Kronsell, E. Lövbrand, and J. Persson. 2011. Structuring sustainability science. Sustainability Science 6(1):69-82. http://dx.doi.org/10.1007/s11625-010-0117-x

Karlin, B., C. C. Kelman, K. A. Goodrich, and V. L. Bredow. 2016. The role of the university: engaged scholarship in the Anthropocene. Pages 143-172 in M. Harron, K. A. Goodrich, B. Maharramli, and E. Niazkorodov, editors. World scientific reference on natural resources and environmental policy in the era of global change. World Scientific, Singapore. http://dx.doi. org/10.1142/97898132081620007
Keck, A.-S., S. Sloane, J. M. Liechty, B. H. Fiese, and S. M. Donovan. 2017. Productivity, impact, and collaboration differences between transdisciplinary and traditionally trained doctoral students: a comparison of publication patterns. PLoS ONE 12(12):1-12. http://dx.doi.org/10.1371/journal.pone.0189391

Kessel, F., P. L. Rosenfield, and N. B. Anderson. 2008. Interdisciplinary research: case studies from health and social science. Oxford University Press, Oxford, UK.

Kidwell, S. M. 2015. Biology in the Anthropocene: challenges and insights from young fossil records. Proceedings of the National Academy of Sciences 112(16):4922-4929. http://dx.doi.org/10.1073/ pnas. 1403660112

Komiyama, H., and K. Takeuchi. 2006. Sustainability science: building a new discipline. Sustainability Science 1(1):1-6. http://dx. doi.org/10.1007/s11625-006-0007-4

Krantz, L. 2001. The sustainable livelihood approach to poverty reduction. Swedish International Development Cooperation Agency, Division for Policy and Socio-Economic Analysis, Stockholm, Sweden. [online] URL: https://www.sida.se/ contentassets/bd474c210163447c9a7963d77c64148a/the-sustainablelivelihood-approach-to-poverty-reduction 2656.pdf

Lang, D. J., A. Wiek, M. Bergmann, M. Stauffacher, P. Martens, P. Moll, M. Swilling, and C. J. Thomas. 2012. Transdisciplinary research in sustainability science: practice, principles, and challenges. Sustainability Science 7(1):25-43. http://dx.doi. org/10.1007/s11625-011-0149-X

Lelea, M. A., G. M. Roba, A. Christinck, and B. Kaufmann. 2014. Methodologies for stakeholder analysis - for application in transdisciplinary research projects focusing on actors in food supply chains. German Institute for Tropical and Subtropical Agriculture, Witzenhausen, Germany. [online] URL: http:// reload-globe.net/cms/attachments/article/56/Lelea et al (2014) StakeholderGuide final web.pdf

Leventon, J., L. Fleskens, H. Claringbould, G. Schwilch, and R. Hessel. 2016. An applied methodology for stakeholder identification in transdisciplinary research. Sustainability Science 11:763-775. http://dx.doi.org/10.1007/s11625-016-0385-1

Lindvig, K. 2018. The implied PhD student of interdisciplinary research projects within monodisciplinary structures. Higher Education Research and Development 6:1171-1185. http://dx.doi. org/10.1080/07294360.2018.1474343

Lindvig, K., C. Lyall, and L. R. Meagher. 2017. Creating interdisciplinary education within monodisciplinary structures: the art of managing interstitiality. Studies in Higher Education 1-14. http://dx.doi.org/10.1080/03075079.2017.1365358

Lombard, M., J. Snyder-Duch, and C. C. Bracken. 2002. Content analysis in mass communication: assessment and reporting of intercoder reliability. Human Communication Research 28 (4):587-604. http://dx.doi.org/10.1111/j.1468-2958.2002.tb00826. $\underline{\mathrm{x}}$

Looney, C., S. Donovan, M. O'Rourke, S. Crowley, S. D. Eigenbrode, L. Rotschy, N. A. Bosque-Pérez, and J. D. Wulfhorst. 2013. Seeing through the eyes of collaborators: using toolbox workshops to enhance cross-disciplinary communication. Pages 
220-243 in M. O'Rourke, S. Crowley, S. D. Eigenbrode, and J. D. Wulfhorst, editors. Enhancing communiction and collaboration in imterdisciplinary research. Sage, Thousand Oaks, California, USA. [online] URL: https://msu.edu/ orourk51/860-Phil/ Handouts/Readings/11-Orourke.pdf

Lyall, C., L. Meagher, J. Bandola, and A. Kettle. 2015. Interdisciplinary provision in higher education: current and future challenges. Higher Education Academy, York, UK. [online] URL: https://www.heacademy.ac.uk/knowledge-hub/interdisciplinary-provisionhigher-education-current-and-future-challenges

Mauser, W., G. Klepper, M. Rice, B. S. Schmalzbauer, H. Hackmann, R. Leemans, and H. Moore. 2013. Transdisciplinary global change research: the co-creation of knowledge for sustainability. Current Opinion in Environmental Sustainability 5 (3-4):420-431. http://dx.doi.org/10.1016/j.cosust.2013.07.001

Meyer, S. R., V. R. Levesque, K. H. Bieluch, M. L. Johnson, B. McGreavy, S. Dreyer, and H. Smith. 2016. Sustainability science graduate students as boundary spanners. Journal of Environmental Studies and Sciences 6(2):344-353. http://dx.doi. org/10.1007/s13412-015-0313-1

Mitrany, M., and D. Stokols. 2005. Gauging the transdisciplinary qualities and outcomes of doctoral training programs. Journal of Planning Education and Research 24(4):437-449. http://dx.doi. org/10.1177/0739456X04270368

Moon, K., and D. Blackman. 2014. A guide to understanding social science research for natural scientists. Conservation Biology 28(5):1167-1177. http://dx.doi.org/10.1111/cobi.12326

Morse, W. C., M. Nielsen-Pincus, J. E. Force, and J. D. Wulfhorst. 2007. Bridges and barriers to developing and conducting interdisciplinary graduate-student team research. Ecology and Society 12(2):8. http://dx.doi.org/10.5751/ES-02082-120208

National Research Council. 2015. Enhancing the effectiveness of team science. N. J. Cooke and M. L. Hilton, editors. Board on Behavioral, Cognitive, and Sensory Sciences, Division of Behavioral and Social Sciences and Education, National Academies Press, Washington, D.C., USA. [online] URL: https:// www.nap.edu/read/19007/chapter/1

Naylor, R. L., A. J. Liska, M. B. Burke, W. P. Falcon, J. C. Gaskell, S. D. Rozelle, and K. G. Cassman. 2007. The ripple effect: biofuels, food security, and the environment. Environment: Science and Policy for Sustainable Development 49(9):30-43. http://dx.doi. org/10.3200/ENVT.49.9.30-43

Newswander, L. K., and M. Borrego. 2009. Engagement in two interdisciplinary graduate programs. Higher Education 58 (4):551-562. http://dx.doi.org/10.1007/s10734-009-9215-z

O'Rourke, M., and S. J. Crowley. 2013. Philosophical intervention and cross-disciplinary science: the story of the Toolbox Project. Synthese 190(11):1937-1954. http://dx.doi.org/10.1007/s11229-012-0175$\mathrm{y}$

Ostrom, E. 2009. A general framework for analyzing sustainability of social-ecological systems. Science 325 (5939):419-422. http://dx.doi.org/10.1126/science.1172133

Palmer, M. A., J. G. Kramer, J. Boyd, and D. Hawthorne. 2016. Practices for facilitating interdisciplinary synthetic research: the
National Socio-Environmental Synthesis Center (SESYNC). Current Opinion in Environmental Sustainability 19:111-122. http://dx.doi.org/10.1016/j.cosust.2016.01.002

Pennington, D., G. Bammer, A. Danielson, D. Gosselin, J. Gouvea, G. Habron, D. Hawthorne, R. Parnell, K. Thompson, S. Vincent, and C. Wei. 2016. The EMBeRS project: employing model-based reasoning in socio-environmental synthesis. Journal of Environmental Studies and Sciences 6(2):278-286. http://dx.doi. org/10.1007/s13412-015-0335-8

Pennington, D. D., G. L. Simpson, M. S. McConnell, J. M. Fair, and R. J. Baker. 2013. Transdisciplinary research, transformative learning, and transformative science. BioScience 63(7):564-573. http://dx.doi.org/10.1525/bio.2013.63.7.9

Pring, R. 2000. The 'false dualism' of educational research. Journal of Philosophy of Education 34(2):247-260. http://dx.doi. org/10.1111/1467-9752.00171

Record, S., P. F. B. Ferguson, E. Benveniste, R. A. Graves, V. W. Pfeiffer, M. Romolini, C. E. Yorke, and B. Beardmore. 2016. Graduate students navigating social-ecological research: insights from the Long-Term Ecological Research Network. Ecology and Society 21(1):7. http://dx.doi.org/10.5751/ES-08111-210107

Reed, M. S. 2008. Stakeholder participation for environmental management: a literature review. Biological Conservation 141 (10):2417-2431. http://dx.doi.org/10.1016/j.biocon.2008.07.014

Reed, M. S., A. Graves, N. Dandy, H. Posthumus, K. Hubacek, J. Morris, C. Prell, C. H. Quinn, and L. C. Stringer. 2009. Who's in and why? A typology of stakeholder analysis methods for natural resource management. Journal of Environmental Management 90(5):1933-1949. http://dx.doi.org/10.1016/j. jenvman.2009.01.001

Reed, M. S., L. C. Stringer, I. Fazey, A. C. Evely, and J. H. J. Kruijsen. 2014. Five principles for the practice of knowledge exchange in environmental management. Journal of Environmental Management 146:337-345. http://dx.doi.org/10.1016/j. jenvman.2014.07.021

Rhoten, D., and A. Parker. 2004. Risks and rewards of an interdisciplinary research path. Science 306(5704):2046. http://dx. doi.org/10.1126/science. 1103628

Rittel, H. W. J., and M. M. Webber. 1973. Dilemmas in a general theory of planning. Policy Sciences 4(2):155-169. http://dx.doi. org/10.1007/BF01405730

Romolini, M., S. Record, R. Garvoille, Y. Marusenko, and S. Geiger. 2013. The next generation of scientists: examining the experiences of graduate students in network-level socialecological science. Ecology and Society 18(3):42. http://dx.doi. org/10.5751/ES-05606-180342

Runge, C. F., and B. Senauer. 2007. How biofuels could starve the poor. Foreign Affairs :41-53.

Ryan, M. M., R. S. Yeung, M. Bass, M. Kapil, S. Slater, and K. Creedon. 2012. Developing research capacity among graduate students in an interdisciplinary environment. Higher Education Research and Development 31(4):557-569. http://dx.doi. org/10.1080/07294360.2011.653956 
Sá, C. M. 2008. 'Interdisciplinary strategies' in U.S. research universities. Higher Education 55(5):537-552. http://dx.doi. org/10.1007/s10734-007-9073-5

Schnapp, L. M., L. Rotschy, T. E. Hall, S. Crowley, and M. O'Rourke. 2012. How to talk to strangers: facilitating knowledge sharing within translational health teams with the Toolbox dialogue method. Translational Behavioral Medicine 2 (4):469-479. http://dx.doi.org/10.1007/s13142-012-0171-2

Scotland, J. 2012. Exploring the philosophical underpinnings of research: relating ontology and epistemology to the methodology and methods of the scientific, interpretive, and critical research paradigms. English Language Teaching 5(9):9. http://dx.doi. org/10.5539/elt.v5n9p9

Shew, A., D. Pennington, D. Gosselin, J. Clifton, A. K. Killion, L. Nalley, P. Owens, K. Sterle, and B. Wilson. 2018. Interdisciplinary science, economic development, and sustainability in Southern Africa: navigating complex human-environmental problems in diverse teams and challenging settings. A participatory workshop for the Swaziland Economic Policy Analysis and Research Center. Swaziland Economic Policy Analysis and Research Center, Mbabane, Swaziland.

Singletary, L., and K. Sterle. 2017. Collaborative modeling to assess drought resiliency of snow-fed river dependent communities in the western United States: a case study in the Truckee-Carson River system. Water 9(2):99. http://dx.doi. org/10.3390/w9020099

Steffen, W., W. Broadgate, L. Deutsch, O. Gaffney, and C. Ludwig. 2015. The trajectory of the Anthropocene: the great acceleration. Anthropocene Review 2(1):81-98. http://dx.doi.org/10.1177/2053$\underline{019614564785}$

Steffen, W., J. Grinevald, P. Crutzen, and J. McNeill. 2011. The Anthropocene: conceptual and historical perspectives. Philosophical Transactions of the Royal Society A: Mathematical, Physical and Engineering Sciences 369(1938):842-867. http://dx.doi.org/10.1098/ rsta.2010.0327

Sterle, K., and L. Singletary. 2017. Adapting to variable water supply in the Truckee-Carson River system, Western USA. Water 9(10):768. http://dx.doi.org/10.3390/w9100768

Stokols, D. 2013. Training the next generation of astrobiologists. Page in M. O'Rourke, S. Crowley, S. D. Eigenbrode, and J. D. Wulfhorst, editors. Enhancing communication and collaboration in interdisciplinary research. Oxford University Press, New York, New York, USA.

Stokols, D. 2017. Social ecology in the digital age solving complex problems in a globalized world. Academic Press, Cambridge, Massachusetts, USA.

Thompson, K., A. Danielson, D. Gosselin, S. Knight, R. Martinez-Maldonado, R. Parnell, D. Pennington, J. SvobodaGouvea, S. Vincent, and P. Wheeler. 2017. Designing the EMBeRS summer school: connecting stakeholders in learning, teaching and research. Page 6 in W. Chen, J.-C. Yang, A. F. Mohd Ayub, S. L. Wong, and A. Mitrovic, editors. Proceedings of the 25 th international conference on computers in education. AsiaPacific Society for Computers in Education, Christchurch, New
Zealand. [online] URL: https://www.sesync.org/sites/default/ files/webform/results/designing the embers_summer_school_short paper pw.pdf

Tilman, D., C. Balzer, J. Hill, and B. L. Befort. 2011. Global food demand and the sustainable intensification of agriculture. Proceedings of the National Academy of Sciences 108 (50):20260-20264. http://dx.doi.org/10.1073/pnas.1116437108

Trencher, G., S. Vincent, K. Bahr, S. Kudo, K. Markham, and Y. Yamanaka. 2018. Evaluating core competencies development in sustainability and environmental master's programs: an empirical analysis. Journal of Cleaner Production 181:829-841. http://dx. doi.org/10.1016/i.jclepro.2018.01.164

Van der Leeuw, S., A. Wiek, J. Harlow, and J. Buizer. 2012. How much time do we have? Urgency and rhetoric in sustainability science. Sustainability Science 7(1):115-120. http://dx.doi. org/10.1007/s11625-011-0153-1

Van Noorden, R. 2015. Interdisciplinary research by the numbers. Nature 525(7569):306-307. [online] URL: https://www.nature. com/news/interdisciplinary-research-by-the-numbers-1.18349

Vincent, S., K. Dutton, R. Santos, and L. Sloane. 2015. Interdisciplinary environmental and sustainability education and research: leadership and administrative structures. Center for Environmental Education Research, National Council for Science, and the Environment for the Council of Environmental Deans and Directors, Washington, D.C., USA.

Yarime, M., G. Trencher, T. Mino, R. W. Scholz, L. Olsson, B. Ness, N. Frantzeskaki, and J. Rotmans. 2012. Establishing sustainability science in higher education institutions: towards an integration of academic development, institutionalization, and stakeholder collaborations. Sustainability Science 7(1):101-113. http://dx.doi.org/10.1007/s11625-012-0157-5 
Appendix 1. Open-ended survey administered to EMBeRS cohorts.

1) Prior to the EMBeRS workshop, have you had any integrative research training (i.e., informal/formal trainings in professional or academic setting)? If so, please explain.

2) Please describe the graduate program you are currently enrolled, your dissertation research topic, and overall, how things are going.

3) In conducting your dissertation research, what barriers (if any) do you face? Please explain and provide examples.

4) In reflecting on the EMBeRS approach, what aspects might be most useful to overcome research barriers? Please explain and provide examples.

5) What recommendations would you make for future integrative research trainings? 